\title{
New records of fruit trees as host for Neosilba species (Diptera, Lonchaeidae) in southeast Brazil
}

\author{
Laura Jane Gisloti ${ }^{1 *}$, Manoel A. Uchoa ${ }^{2}$, Angelo Prado \\ ${ }^{1}$ Universidade Federal da Grande Dourados, Faculdade de Ciências Biológicas e Ambientais, \\ Rod. Dourados-Itahum, Dourados, MS, Brazil \\ ${ }^{2}$ Universidade Federal da Grande Dourados, R. João Rosa Góes, 1761 - Vila Progresso, Dourados, MS, Brasil \\ ${ }^{3}$ Universidade Estadual de Campinas, Instituto de Biologia, Campinas, SP, Brazil \\ *Corresponding author: Laura Jane Gisloti,e-mail: lauragisloti@gmail.com
}

GISLOTI, L. J., UCHOA, M. A., PRADO, A. New fruit trees host for Neosilba (Diptera, Lonchaeidae) species in southeast Brazil. Biota Neotropica. 17(1): e20160213. http://dx.doi.org/10.1590/1676-0611-BN-2016-0213

\begin{abstract}
Fruits of thirty-five cultivated native plant species (19 orders and 12 families) were sampled in farms of fruit production from two municipalities of São Paulo state, Brazil (January 2010 to March 2012) to evaluate species diversity of Neosilba flies. Thirty-one species of plants were the host for Neosilba species while four were not infested. Some aspects of the biology and patterns of species diversity, abundance, infestation rates, puparias viability and the interactions among species of frugivorous flies and their host plants were quantified. Seven species of Neosilba were reared: Neosilba bella Strikis \& Prado (4 hosts), Neosilba certa (Walker) (4 hosts), Neosilba glaberrima (Wiedemann) (5 hosts), Neosilba inesperata Strikis \& Prado (6 hosts) Neosilba pendula (Bezzi) (15 hosts), Neosilba pradoi Strikis $\&$ Lerena (8 hosts) and Neosilba zadolicha McAlpine (26 hosts). The association between the lance flies and the host fruit species is discussed.
\end{abstract}

Keywords: Hosts; Lance Flies; Lonchaeid; Natural history.

\section{Novos registros de espécies de plantas hospedeiras para espécies de Neosilba (Diptera, Lonchaeidae) no sudeste do Brasil}

\begin{abstract}
Resumo: Foram coletados frutos de trinta e cinco espécies de plantas nativas (19 ordens e 12 famílias) de janeiro de 2010 a março de 2012, em pomares de produção de frutos em dois municípios do estado de São Paulo, Brasil, à fim de avaliar a diversidade de espécies de Neosilba. Trinta e uma espécies das plantas amostradas foram colonizadas por espécies de Neosilba, enquanto quatro não estavam infestadas. Foram quantificados alguns aspectos da biologia, dos padrões de diversidade de espécies, abundância, taxas de infestação, viabilidade pupal e aspectos da interação entre espécies de moscas frugívoras e suas plantas hospedeiras. Sete espécies de Neosilba foram criadas: Neosilba bella Strikis \& Prado (4 plantas hospedeiras), Neosilba certa (Walker) (4 plantas hospedeiras), Neosilba glaberrima (Wiedemann) (5 plantas hospedeiras), Neosilba inesperata Strikis \& Prado (6 plantas hospedeiras) Neosilba pendula (Bezzi) (15 plantas hospedeiras), Neosilba pradoi Strikis \& Lerena (8 plantas hospedeiras) e Neosilba zadolicha McAlpine (26 plantas hospedeiras). A associação entre as espécies de Neosilba e as espécies de frutas hospedeiras é discutida.
\end{abstract}

Palavras-chave: frutos hospedeiros; moscas das frutas; lonqueideos; história natural.

\section{Introduction}

The Neotropical genus Neosilba McAlpine (Diptera: Lonchaeidae) is comprised of fly species whose larvae feeds on many species of commercially important fruit species (Araújo \& Zucchi 2002, Strikis $\&$ Prado 2005, Bittencourt et al. 2006). The genus is restricted to the Neotropical region, being known from Caribe, Mexico, and Colombia to Brazil. Forty species were described so far and at least more 60 species are waiting for descriptions (McAlpine \& Steyskal 1982, Strikis 2011; Galeano-Olaya \& Canal 2012).

Although of the economic importance of some species of Neosilba that occur as pests on fruit and vegetables in several countries, such as Colombia (Steyskal 1978, Peñaranda et al. 1986), Peru (Korytkowski \&
Ojeda 1971), Costa Rica (Sánchez et al. 1991), and Brazil, the knowledge of these dipterans is still very scarce (Uchoa et al. 2002).

Neosilba species obtains food resource in 113 plant species distributed in 39 families: Anacardiaceae, Annonaceae, Apocynaceae, Arecaceae, Bignoniaceae, Bombacaceae, Cactaceae, Caricaceae, Chrysobalanaceae, Combretaceae, Convolvulaceae, Cucurbitaceae, Ebenaceae, Euphorbiaceae, Fabaceae, Flacourtiaceae, Gnetaceae, Lauraceae, Lecythidaceae, Loganiaceae, Loranthaceae, Malpighiaceae, Malvaceae, Melastomataceae, Moraceae, Musaceae, Myrtaceae, Olacaceae, Oxalidaceae, Passifloraceae, Rhamnaceae, Rosaceae, Rubiaceae, Rutaceae, Sapotaceae, Solanaceae, Ulmaceae, Verbenaceae, and Vitaceae, confirming the relevance of this genus of fruit flies to tropical fruit and horticulture production (McAlpine 
\& Steyskal 1982, Raga et al. 1996, Raga et al. 2015, Araújo \& Zucchi 2002; Uchoa et al. 2012).

Studies on the biology and ecology of economically important species of fruit flies have contributed for the management and control of agricultural pests (Carey 1993, Vargas et al. 2001, Papadopoulos et al. 2002). Integrated pest management has been more difficult by the lack of basic studies on taxonomy, biology, and ecology. In Brazil, records on the genera of Lonchaeidae associated with fruits are scarce. Regional surveys are very important because they can provide basic information for managing insect pest populations and their natural enemies (Uchoa et al. 2002).

Our hypothesis is that there are new associations between Neosilba species and native host fruit species in the southeast of Brazil.

The aim of this study was to provide original information on fruit infestation rates, puparia's viability and interactions with species of host plants by Neosilba species in fruits sampled in the southeast of Brazil.

\section{Material and Methods}

Characterization of the study area. These orchards are located in an important fruit producing area in the state of São Paulo, Brazil. According to Setzer (1976), the regions are inserted in a climatic transition between very humid subtropical with marked dry seasons $(\mathrm{Mu}-\mathrm{Cw})$, with mean temperatures around $24^{\circ} \mathrm{C}$ and minimum temperatures around $16^{\circ} \mathrm{C}$ in the summer. Mean annual precipitation is about $1,300 \mathrm{~mm} /$ year and the predominant soil type in the studied areas is Latosol with good aeration, permeability and drainage.

Collecting of the Host Fruits. Fruits from 35 species (Table 1) were sampled from January 2010 to March 2012, in fruit farms from the municipalities of Campina do Monte Alegre (23 53' $37^{\prime}$ ' S, 48 $41^{\circ}$ ' $06^{\prime}$ ' W, $612 \mathrm{~m})$ (site 1), and Paraibuna (23 $\left.27^{\prime} 94^{\prime \prime} \mathrm{S}, 45^{\circ} 42^{\prime} 88^{\prime \prime} \mathrm{W}, 647 \mathrm{~m}\right)$ (site 2). On a monthly basis fruits were collected from each studied area. The mature fruits were collected directly from the plant and the amount of

Table 1. Indices of infestation and puparia's viability of Neosilba species (Diptera, Lonchaeidae) in 35 cultivated native host fruits from southeast Brazil (January 2010 to March 2012).

\begin{tabular}{|c|c|c|c|c|c|c|c|c|c|c|c|c|c|c|c|}
\hline \multicolumn{6}{|c|}{ Plant Taxa } & \multicolumn{7}{|c|}{ Neosilba male species } & \multicolumn{3}{|c|}{ Indices/Rate } \\
\hline & 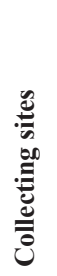 & 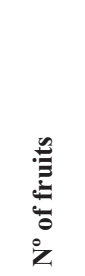 & 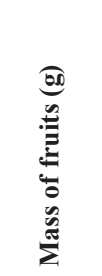 & 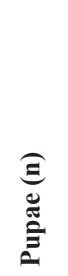 & 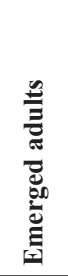 & $\begin{array}{l}\Xi \\
\Xi \\
\vdots\end{array}$ & $\begin{array}{l}5 \\
\bar{z} \\
\dot{z} \\
z\end{array}$ & 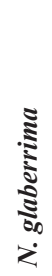 & 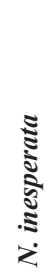 & 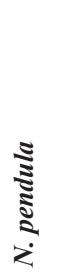 & $\begin{array}{l}\tilde{3} \\
\overline{3} \\
\vdots \\
\dot{z}\end{array}$ & 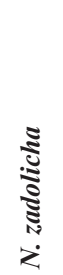 & 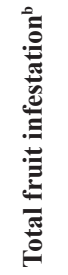 & 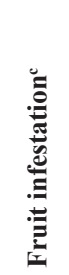 & 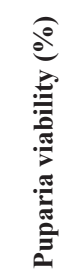 \\
\hline Anacardiaceae & & & & & & & & & & & & & & & \\
\hline Spondias mombim L. & 2 & 620 & 11,160 & 384 & 289 & - & 48 & - & - & 22 & - & 83 & 0.62 & 0.03 & 75.26 \\
\hline Spondias purpurea $\mathrm{L}$. & 2 & 460 & 3,220 & 189 & 102 & - & - & - & - & 17 & - & 50 & 0.41 & 0.06 & 53.97 \\
\hline Spondias tuberosa Arruda & 2 & 1,280 & 19,200 & 412 & 302 & - & - & - & - & - & - & 127 & 0.32 & 0.02 & 73.30 \\
\hline Spondias venulosa Mart. & 1 & 367 & 5505 & 113 & 81 & - & - & - & - & - & - & 54 & 0.31 & 0.02 & 71.68 \\
\hline Annonaceae & & & & & & & & & & & & & & & \\
\hline $\begin{array}{l}\text { Rollinia sylvatica (A. St.-Hil.) } \\
\text { Apocynaceae }\end{array}$ & 1 & 67 & 5,360 & 64 & 50 & - & - & 6 & - & - & - & 12 & 0.96 & 0.01 & 78.13 \\
\hline $\begin{array}{l}\text { Hancornia speciosa Gomes } \\
\text { Arecaceae }\end{array}$ & 1 & 543 & 10,860 & 184 & 101 & - & - & - & - & - & - & 51 & 0.34 & 0.02 & 54.89 \\
\hline $\begin{array}{l}\text { Bactris gasipaes Kunth } \\
\text { Cactaceae }\end{array}$ & 1 & 521 & 26,050 & 101 & 78 & - & - & 12 & - & - & - & 32 & 0.19 & 0.00 & 77.23 \\
\hline Selenicereus setaceus (Rizz) & 2 & 62 & 7,740 & 37 & 25 & - & - & 12 & - & - & - & - & 0.60 & 0.00 & 67.57 \\
\hline Caryocaraceae & & & & & & & & & & & & & & & \\
\hline $\begin{array}{l}\text { Caryocar brasiliense Camb. } \\
\text { Fabaceae }\end{array}$ & 2 & 82 & 7,380 & 189 & 134 & - & - & - & - & 42 & - & 12 & 2.30 & 0.03 & 70.90 \\
\hline $\begin{array}{l}\text { Inga vera Willd. } \\
\text { Malphigiaceae }\end{array}$ & 1 & 512 & 7,680 & 201 & 171 & - & 10 & - & - & 14 & 8 & 53 & 0.39 & 0.03 & 85.07 \\
\hline Byrsonima crassifolia $(\mathrm{L})$. & 2 & 843 & 1,011 & 234 & 189 & 30 & - & - & - & - & - & 71 & 0.28 & 0.23 & 80.77 \\
\hline $\begin{array}{l}\text { Malpighia emarginata DC. } \\
\text { Myrtaceae }\end{array}$ & 2 & 1,384 & 4,152 & 389 & 302 & 11 & - & 37 & 53 & 21 & 12 & 33 & 0.28 & 0.09 & 77.63 \\
\hline Acca sellowiana (Berg.) & 2 & 100 & 5,178 & 42 & 21 & - & - & - & - & - & - & 7 & 0.42 & 0.01 & 50.00 \\
\hline Campomanesia aurea Berg. & 2 & 189 & 4,725 & 47 & 19 & - & - & - & - & - & 8 & - & 0.25 & 0.01 & 40.43 \\
\hline Campomanesia guazumaefolia (Camb.) & 1 & 112 & 2,688 & 45 & 21 & - & - & - & - & - & 3 & 6 & 0.40 & 0.02 & 46.67 \\
\hline Campomanesia phaea (Berg.) & 1 & 229 & 8,450 & 79 & 54 & - & - & - & - & - & 9 & 12 & 0.34 & 0.01 & 68.35 \\
\hline Campomanesia sessiflora (Berg.) & 1 & 340 & 6,667 & - & - & - & - & - & - & - & - & - & - & - & - \\
\hline Eugenia brasiliensis Lam. & 2 & 670 & 1,150 & 231 & 120 & - & - & - & - & 12 & - & 31 & 0.34 & 0.20 & 51.95 \\
\hline Eugenia dysenterica (DC.) & 2 & 578 & 8,670 & 289 & 201 & - & - & - & 43 & 20 & 11 & 40 & 0.50 & 0.03 & 69.55 \\
\hline Eugenia involucrata DC. & 2 & 539 & 1,340 & 211 & 160 & - & - & - & - & 12 & - & 61 & 0.39 & 0.16 & 75.83 \\
\hline
\end{tabular}

a Site 1: Campina do Monte Alegre; site 2: Paraibúna (São Paulo, Brazil);

${ }^{b}$ Number of puparia/number of fruit;

${ }^{\mathrm{c}}$ Number of puparia/weight of fruits (in grams). 
Table 1. Continued...

\begin{tabular}{|c|c|c|c|c|c|c|c|c|c|c|c|c|c|c|c|}
\hline \multicolumn{6}{|c|}{ Plant Taxa } & \multicolumn{7}{|c|}{ Neosilba male species } & \multicolumn{3}{|c|}{ Indices/Rate } \\
\hline & 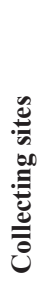 & 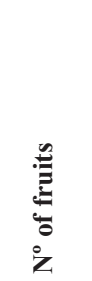 & 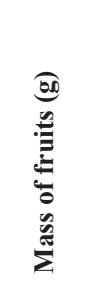 & 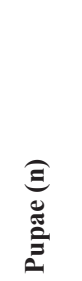 & 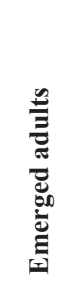 & $\begin{array}{l}\stackrel{\Xi}{\Xi} \\
\check{z} \\
z\end{array}$ & 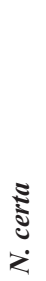 & 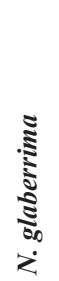 & 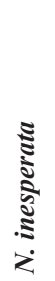 & 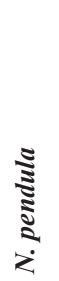 & 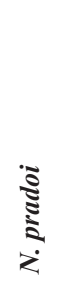 & 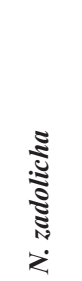 & 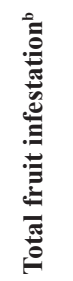 & 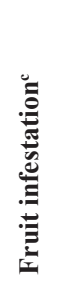 & 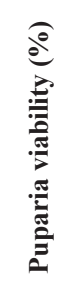 \\
\hline Eugenia matosii Legr. & 1 & 501 & 8,020 & - & - & - & - & - & - & - & - & - & - & - & - \\
\hline Eugenia neonitida Sobral & 1 & 1,279 & 3,837 & 467 & 321 & - & - & - & - & 27 & - & 102 & 0.37 & 0.12 & 68.74 \\
\hline Eugenia pitanga (Berg.) & 1 & 1,021 & 3,063 & 312 & 204 & - & - & - & - & - & - & 81 & 0.31 & 0.10 & 65.38 \\
\hline Eugenia pyriformis Cambess & 2 & 1,342 & 8,910 & 380 & 289 & - & - & - & - & - & 46 & 101 & 0.28 & 0.04 & 76.05 \\
\hline Eugenia stipitata McVaugh & 2 & 234 & 3,880 & 98 & 69 & 2 & - & - & - & 31 & - & - & 0.42 & 0.00 & 70.41 \\
\hline Eugenia uniflora L. & 2 & 2,295 & 4,704 & 467 & 332 & 8 & - & - & 119 & - & - & 22 & 0.20 & 0.10 & 71.09 \\
\hline Myrciaria dubia McVaugh & 2 & 829 & 9,119 & 231 & 167 & - & - & - & - & - & - & 61 & 0.28 & 0.03 & 72.29 \\
\hline Myrciaria jaboticaba Baill. & 2 & 801 & 8,604 & - & - & - & - & - & - & - & - & - & - & - & - \\
\hline Psidium cattleianum Sabine & 1 & 876 & 5,310 & 465 & 398 & & 22 & & 34 & 17 & 27 & 101 & 0.53 & 0.09 & 85.59 \\
\hline Psidium guajava L. & 1 & 335 & 33,890 & 189 & 89 & - & 10 & - & 5 & 4 & - & 21 & 0.56 & 0.01 & 47.09 \\
\hline Psidium guineense Swartz. & 2 & 378 & 60,480 & 168 & 102 & - & - & - & - & 2 & - & 41 & 0.44 & 0.00 & 60.71 \\
\hline \multicolumn{16}{|l|}{ Rhamnaceae } \\
\hline Ziziphus joazeiro Mart. & 1 & 521 & 2,605 & 232 & 171 & - & - & - & - & 68 & - & - & 0.45 & 0.09 & 73.71 \\
\hline \multicolumn{16}{|l|}{ Rosaceae } \\
\hline Rubus urticaefolius Poir & 1 & 594 & 3564 & 281 & 188 & - & - & - & 33 & 31 & - & - & 0.47 & 0.08 & 66.90 \\
\hline \multicolumn{16}{|l|}{ Sapotaceae } \\
\hline Pouteria caimito (Ruiz and Pav.) & 2 & 549 & 1,6470 & 179 & 102 & - & - & 42 & - & - & - & 24 & 0.33 & 0.01 & 56.98 \\
\hline Pouteria macrophylla (Lam.) & 2 & 443 & 15071 & - & - & - & - & - & & - & - & - & - & - & - \\
\hline Total & - & 21,496 & & 6,910 & 4,852 & 51 & 90 & 109 & 287 & 340 & 124 & 1,289 & - & - & - \\
\hline Mean & - & - & - & - & - & - & - & - & - & - & - & - & 0.46 & 0.05 & 67.23 \\
\hline
\end{tabular}

aSite 1: Campina do Monte Alegre; site 2: Paraibúna (São Paulo, Brazil);

${ }^{b}$ Number of puparia/number of fruit;

${ }^{\mathrm{N}}$ Number of puparia/weight of fruits (in grams).

fruits collected in each sample varies depending on the availability of fruit at the time of sampling. Were collected about 50 fruits per specie plant on average. The samples (fruits individualized) were kept at room temperature and humidity, stored in plastic boxes $(25 \times 50 \times 10 \mathrm{~cm})$ sealed with nylon organza and lined with moist, autoclaved fine sand $( \pm 2 \mathrm{~cm}$ layer $)$ as a substrate for larval pupation. After the larvae had pupated 15 to $25 \mathrm{~d}$ after the material was brought in from the field, the substrate was sieved to collect the puparia, which were counted and transferred to emergence boxes kept under the same environmental conditions. Daily over a period of $40 \mathrm{~d}$, substrate humidity was checked and the emergence of flies and parasitoids was monitored. The emerged parasitoids were fed with honey and water for $3 \mathrm{~d}$, to fix the coloring that would allow their correct identification. They were then killed and preserved in $85 \%$ ethanol in labeled flasks for subsequent counting and species identification (Uchoa \& Zucchi 1999).

Fly Identification. The adults were identified in the Departamento de Biologia Animal, Instituto de Biologia, Universidade Estadual de Campinas (Unicamp), Campinas-SP, by the first author. Neosilba species were identified using keys and original descriptions (Korytkowski \& Ojeda 1971, McAlpine \& Steyskal 1982, Strikis 2011, Galeano-Olaya \& Canal 2012). Only males were used since the group taxonomy is based on analysis of male genitalia (McAlpine \& Steyskal 1982). Plant species were identified by botanists at the Departamento de Botânica, Universidade Estadual de Campinas (Unicamp), Campinas, SP, Brazil. Voucher specimens of the insects (stored in $85 \%$ alcohol) were deposited at Coleção Zoológica (ZUEC), Universidade Estadual de Campinas (UNICAMP), Campinas, SP, Brazil.

Quantitative variables, infestation indexes, and viability of the puparia. Two quantitative variables were evaluated: the number of puparia and of emerged flies. The fruit infestation levels were evaluated by two indexes: number of puparia/fruit, and the number of puparia/mass $(\mathrm{g})$ of fruit. The viability of the puparia was calculated by the equation: $\% \mathrm{~V}=$ No. of EA/ PUP) X 100, where: $\% \mathrm{~V}=$ Percent of viability), No. of $\mathrm{EA}=$ number of emerged adults, and $\mathrm{PUP}=\mathrm{A}$ total number of puparia; and the quotient was multiplied by 100 .

Faunistic analysis. The faunistic analysis of Neosilba species was conducted according to Silveira-Neto et al. (1976). The following parameters were estimated: frequency, dominance, abundance, and constancy, using the Anafau software developed by the Departamento de Entomologia, Fitopatologia e Zoologia Agrícola, ESALQ/USP (Moraes et al. 2003):

Frequency: Number of individuals of one species divided by the total number of individuals in the sample.

Dominance: The ratio given by the number of individuals of a given species divided by the number of individuals of all collected species. A species is considered dominant when its frequency is higher than $1 / \mathrm{S}$. ( $\mathrm{S}=$ total number of species in the community). Species classification according to dominance: Super-dominant (sd): number of individuals is higher than the upper limit of the $5 \%$ confidence interval (CI). Dominant (d): number of individuals is within the range of the $5 \%$ CI. Non-dominant (nd): number of individuals is lower than the lower limit of the $5 \%$ CI.

Abundance: Refers to the number of individuals of a given taxonomical category per unit of surface or volume. Species abundance was classified into five categories, as follows: Super-abundant (sa): number of individuals is higher than the upper limit of the $1 \% \mathrm{CI}$; Very abundant (va): number of individuals is situated between the upper limits of the $5 \%$ and $1 \%$ confidence intervals; Common (c): number of individuals is within the 
$5 \%$ CI range; Dispersed (d): number of individuals is situated between the lower limits of the $5 \%$ and $1 \%$ confidence intervals, and Rare (r): number of individuals is lower than the lower limit of the $1 \%$ CI.

Constancy: Percentage of samples in which a given species is present. Species constancy was classified into three categories: Constant (w): when the species was present in more than 50\% of collections; Accessory (y): when the species was present in $25 \%$ to $50 \%$ of collections; Accidental (z): when the species was present in less than $25 \%$ of the collections.

\section{Results}

Host Fruit Species. Seven Neosilba species were reared: N. bella Strikis \& Prado, N. certa (Walker), N. glaberrima (Wiedemann), $N$. inesperata Strikis \& Prado, N. pendula (Bezzi), N. pradoi Strikis \& Lerena and $N$. zadolicha McAlpine. The highest number of individuals belong to $N$. zadolicha (1,289 individuals), followed by $N$. pendula (340). Both species are generalists, infesting 26 species of host fruits. $N$. bella was less abundant (51 individuals) (Table 1).

Out of 35 fruit species sampled, belonging to 12 different families, were obtained 2290 frugivorous flies from 31 plant species. No adult of Neosilba emerged from four host fruit species: Campomanesia sessiflora (Berg.), Eugenia matosii Legr., Myrciaria jaboticaba Baill. (Myrtaceae), and Pouteria macrophylla (Lam.) (Sapotaceae) (Table 1).

$N$. bella $(\mathrm{n}=51)$ was the only species that occurred in only one site (site 2), and this species had the lowest number of host fruit (4 species) from two plant families: Byrsonima crassifolia (L.), Malpighia emarginata DC. (Malphigiaceae), Eugenia stipitata McVaugh and Eugenia uniflora L. (Myrtaceae).

N. certa (90 individuals) also had four species of host fruits, occurring in three plant family: Spondias mombin L. (Anacardiaceae), Inga vera Willd. (Fabaceae), Psidium cattleianum Sabine, and Psidium guajava L. (Myrtaceae).

N. glaberrima $(\mathrm{n}=109)$ hosted five fruit species from five families: Rollinia sylvatica (A. St.-Hil.) (Annonaceae), Bactris gasipaes Kunth (Arecaceae), Selenicereus setaceus (Rizz) (Cactaceae), M. emarginata (Malpighiaceae), and Pouteria caimito (Ruiz \& Pav.)(Sapotaceae) (Table 1). $N$. inesperata $(\mathrm{n}=287)$ was found in six host fruit from three families: Malpighia emarginata (Malpighiaceae), Eugenia dysenterica (DC.), E. uniflora, P. cattleianum, P. guajava (Myrtaceae), and Rubus urticaefolius Poir (Rosaceae) (Table 1).
$N$. pendula $(\mathrm{n}=340)$ infested 15 host fruit species, from seven plant family: S. mombin, Spondias purpurea L. (Anacardiaceae), Caryocar brasiliense Camb. (Caryocaceae), I. vera (Fabaceae), M. emarginata (Malpighiaceae), Eugenia brasiliensis Lam., E. dysenterica, Eugenia involucrata DC.,Eugenia neonitida Sobral, E. stipitata, P. cattleianum, P. guajava, Psidium guineensis Swartz. (Myrtaceae), Ziziphus joazeiro Mart. (Rhamnaceae), and R. urticaefolius (Rosaceae)

$N$. pradoi $(\mathrm{n}=124)$ was recovered from eight fruit species, from three families: I. vera (Fabaceae), M. emarginata (Mapighiaceae), Campomanesia aurea Berg.,Campomanesia guazumaefolia (Camb.), Campomanesia phaea (Berg.), E. dysenterica, Eugenia pyriformis Cambess and P. cattleianum (Myrtaceae).

$N$. zadolicha $(\mathrm{n}=1,289)$ occurred in 25 fruit species from seven plant family: S. mombim, $S$. purpurea, S. purpurea, Spondias tuberosa Arruda, Spondias venulosa Mart. (Anacardiaceae), Rollinia silvatica (Annonaceae), Hancornia speciosa Gomes (Apocynaceae), B. gasipaes (Arecaceae), C. brasiliense (Caryocaraceae), I. vera (Fabaceae), B. crassifolia, M. emarginata (Malpighiaceae), Acca sellowiana (Berg.), C. guazumaefolia, C. phaea, E. brasiliensis, E. dysenterica, E. involucrata, E. neonitida, Eugenia pitanga (Berg.), E. pyriformis, E. uniflora, Myrciaria dubia McVaugh, P. cattleianum, P. guajava, P. guineensis (Myrtaceae), and $P$. caimito (Sapotaceae).

Malpighiae marginata was the host fruit species with the highest Neosilba diversity: six species, being all of them found in this work, with the exception of $N$. certa. Strikis et al. (2011) also found no association record between N. certa and Malpighia sp. in his survey about frugivorous flies in the Amazon Rain Forest. P.cattleianum was the host with the largest number of Neosilba specimens, from which emerged 398 individuals (males + females).

Infestation Indexes and Puparia's Viability. The mean of infestation was: 0.46 (puparia / total fruit) and 0.05 (puparia / fruit weight in grams). The mean of the viability of the puparia was $67.23 \%$. C. brasiliensis was the plant species that showed the highest infestation indexes based on the number of fruit (2.30 puparia / fruit) and, B. crassifolia was the plant species presented the highest infestation indexes based on the mass of fruit ( 0.23 puparium/ mass in grams).

Faunistic analysis. The faunistica analysis is shown in Table 2. The Shannon diversity index (H), Equitability index (E) and Margalef $(\alpha)$ indexes were similar between the two areas. Neosilba zadolicha was the most frequent, most dominant and the most abudant specie. Neosilba bella was the less frequent specie. Faunistic indices classified all species as "accidental". (Table 2).

Table 2. Faunistic analysis of Neosilba spp. (Diptera, Lonchaeidae) in southeast Brazil (January 2010 to March 2012 ).

\begin{tabular}{|c|c|c|c|c|c|c|c|}
\hline Species & Area 1 & Area 2 & Total & $\mathbf{F}^{1}$ & $\mathbf{C}^{2}$ & $\mathbf{D o}^{3}$ & $\mathbf{A}^{4}$ \\
\hline Neosilba bella & 51 & 0 & 51 & Lf & $\mathrm{Z}$ & $\mathrm{D}$ & $\mathrm{d}$ \\
\hline Neosilba certa & 42 & 48 & 90 & $\mathrm{f}$ & Z & $\mathrm{D}$ & $\mathrm{c}$ \\
\hline Neosilba glaberrima & 55 & 54 & 109 & $\mathrm{f}$ & $\mathrm{Z}$ & $\mathrm{D}$ & $\mathrm{c}$ \\
\hline Neosilba inesperata & 101 & 186 & 287 & Vf & $\mathrm{Z}$ & $\mathrm{D}$ & $\mathrm{a}$ \\
\hline Neosilba pendula & 159 & 181 & 340 & Vf & $\mathrm{Z}$ & $\mathrm{D}$ & va \\
\hline Neosilba pradoi & 67 & 57 & 124 & $\mathrm{f}$ & $\mathrm{Z}$ & $\mathrm{D}$ & $\mathrm{c}$ \\
\hline Neosilba zadolicha & 789 & 500 & 1289 & Sf & $\mathrm{Z}$ & $\mathrm{Sd}$ & sa \\
\hline Total & 1264 & 1026 & 2290 & & & & \\
\hline $\mathrm{H}^{5}$ & 1.6755 & 1.4248 & & & & & \\
\hline$\alpha^{6}$ & 0.8113 & 0.7211 & & & & & \\
\hline$E^{7}$ & 0.9351 & 0.7952 & & & & & \\
\hline
\end{tabular}

${ }^{1} \mathrm{~F}=$ Frequency - Lf: little frequent, F: frequent, Mf: Vf frequent; Sf: super frequent;

${ }^{2} \mathrm{C}=$ Constancy $-\mathrm{Z}$ : Accidental

${ }^{3}$ Do $=$ Dominance - D: dominant; Sd: super dominant;

${ }^{4}$ Abundance $=\mathrm{d}$ : dispersed; c: common; a: abundant; va; very abundant; sa: super abundant

${ }^{5} \mathrm{H}^{\prime}=$ Shannon-Wiener diversity index

${ }^{6} \alpha=$ Margalef diversity index.

${ }^{7} \mathrm{E}=$ Equitability index 


\section{Discussion}

Seven Neosilba species were recorded (Table 1), and this species richness is within the range reported in other inventories carried out in the state of São Paulo. In a previous study carried out in the municipality of Monte Alegre do Sul, Souza-Filho et al. (2009) reported eight species during a sampling period of one year. Silva et al. (2006) carried out a two-year study in two locations in the Southern Brazil, and reported five Neosilba species. In the south in the east-west direction across the state of Mato Grosso do Sul, nine species were registered (Nicácio \& Uchoa 2011).

Neosilba zadolicha was the most predominant, frequent, dominant and abundant species indicating its importance in the region (Table 2). This species is a very common in citrus orchards reaching high rates of infestation (Uchoa et al. 2002, Raga et al. 2006, Raga et al. 2011). State of São Paulo has approximately 600,000 hectares of sweet oranges [Citrus sinensis (L.) Osbeck], with different varieties fruiting all year long. This fact may contribute to the abundance, dominance and constancy of N. zadolicha (Raga et al. 2015).

In our study, all species captured presented low constancy being considered accidental. This result suggests that adults of the low constancy species were not resident on the orchards, but they came from other hosts nearby the farm and/or the surrounding forest area. The sampled areas are surrounded by one of the few and largest remnants of the highly endangered mature coastal rainforest in Brazil (Faria et al. 2006). The Brazilian Atlantic rainforest is considered one of the richest biomes on earth, and southwest São Paulo harbors high species richness, high levels of endemism and local sites of diversity of trees in families that comprise species which are known hosts of Neosilba, such as Fabaceae, Malpighiaceae, Myrtaceae, Rutaceae, and Sapotaceae (Thomas et al. 1998, Faria et al. 2006, Martini et al. 2007). Thus, the forest areas surrounding the orchards can provide an important reservoir for lonchaeid populations that probably migrate to the orchards. The movement of fruit flies from the adjacent native vegetation, particularly forest fragments, into orchards was demonstrated by Vargas et al. (2001), and Kovaleski et al. (1999).

Uchoa et al. (2002) found Neosilba species infesting fruits of C. sessiflora and M. jaboticaba in the cerrado of Mato Grosso do Sul, Brazil, and Strikis et al. (2011) found N. glaberrima and N. zadolicha in P. macrophylla fruits, but in this paper, we did not record these associations. Many different biotic and abiotic stimuli can account for the presence of the lesser abundant fruit flies species in environments that do not provide optimal host plants, such as commercial orchards (Aluja et al 1996). The authors suggest that the odor of ripening fruit, shelter conditions of perennial trees, and emission of volatiles by certain tree species that are similar to those found in the sexual pheromones of fruit flies could draw adult fruit flies into the orchard.

Adaime et al. (2012), recorded N. bella in B. crassifolia in the Amazon region. Bittencourt et al. (2013) reared N. bella from E. stipitata fruits in northeastern Brazil. In previous surveys, $N$. bella have been found in twelve plant species from nine plant families (Table 2).

According to Bittencourt et al. (2013), N. bella has a wide geographical distribution in Brazil, ranging from Atlantic Forest, Amazon Rain Forest, and Cerrado. Its plasticity in occupying such different biomes, and attacking different host plants, makes this species a candidate in becoming an important pest, once it is found in environments occupied by crops plantation, especially coffee crops. However, $N$. bella was one of the species with the lowest number of host fruit recorded in this research.

McAlpine \& Steyskal (1982) also found N. certa in I. vera, and Souza-Filho et al. (2009) recorded this species in orchards of P. guajava. $N$. certa has already been registered in fifty host fruits, belonging to seventeen plant families (Table 2).

Strikis et al. (2011) recorded $N$. glaberrima in M. emarginata, and Raga et al. (2003), Strikis et al. (2011), and Fernandes et al. (2013) found this species in P. caimito. N. glaberrima has already been registered in thirty-eight fruit species in sixteen botanical families (Table 2).

$N$. inesperata had already been reported in twenty-eight host fruits in sixteen plant families (Table 2). This species was previously reported by Nicácio \& Uchoa (2011) in P. guajava. Raga et al. (2015) also found this species in $M$. emarginata.

In the literature $N$. pendula had already been reported infesting fifty-five host fruit species from twenty-five plant families. Seventeen plant species from nine families have been reported previously as hosts of $N$. pradoi (Table 1). N. zadolicha has already been recorded in ninety-four host species from thirdy-two plant families (Table 1).

Malpighia emarginata was the host fruit species with the highest Neosilba diversity: six species, being all of them found in this work, with the exception of $N$. certa. Strikis et al. (2011) also found no association record between $N$. certa and Malpighia sp. in his survey about frugivorous flies in the Amazon Rain Forest. P. cattleianum was the host with the largest number of Neosilba specimens, from which emerged 398 individuals (males + females).

Adaime et al. (2012) found lower infestation indexes to that found in this work: 0.06 puparia/fruit to $N$. bella hosted in B. crassifolia. Aguiar-Menezes et al. (2004) reported to N. zadolicha hosted in P. alata infestation index (2.1 puparia/fruit) higher than all indexes found herein.

Souza et al. (2012) reported infestation indexes to Neosilba species hosted in $P$. guajava (0.03 puparia/ g of fruit) similar than mass fruit infestation that was found here (0.01 puparia/ $g$ of fruit). However to Neosilba species hosted in Z. joazeiro, Souza et al. (2012) found higher infestation indexes (3.28 puparia/ $\mathrm{g}$ of fruit) than the herein obtained (0.09 puparia/g of fruit).

Araújo \& Zucchi (2002) found similar infestation indexes to $N$. pendula hosted in S. purpurea, M. emarginata and in P. guajava $(0.06,0.1$ and 0.1 puparia/g of fruit, respectively), however to Z. joazeiro ( 0.2 puparia/g of fruit) those authors found infestation indexes higher than reported in this paper (0.09).

\section{Conclusion - New Records}

In this work were reported the following new records of Neosilba fruit trees host in southeast Brazil:

N. bella in E. uniflora.

$N$. certa in $P$. cattleianum and $S$. mombin.

$N$. glaberrima in B. gasipaes, $R$. sylvatica, and $S$. setaceous.

$N$. inesperata in E. dysenterica, E. uniflora, P. cattleianum, and $R$. urticaefolius. $N$. pendula in E. brasiliensis, E. dysenterica, E. involucrate, E. neonitida, E. stipitata, I. vera, P. guineensis, R. urticaefolius, and S. mombin. $N$. pradoi in C. aurea, C. guazumaefolia, C. phaea, and E. dysenterica. N. zadolicha in A. sellowiana, B. gasipaes, C. brasiliense, C. guazumaefolia, C. phaea, E. brasiliensis, E. dysenterica, E. involucrata, E. neonitida, E. pitanga, E. pyriformis, I. vera, M. emarginata, M. dubia, P. guineensis, P. alata, S. mombim, S. tuberose, and S. venulosa.

\section{Acknowledgments}

We thank the botanist Dr. Washington Marcondes from the Herbarium of the Universidade Estadual de Campinas (UNICAMP Campinas-SP, Brazil), who supported us in identifying the plant species; CNPq-Conselho Nacional de Desenvolvimento Científico e Tecnológico by the grant (Processo: 305112/2012-0) based on research productivity to M. A. Uchoa, and FUNDECT/CAPES-Coordenação de Aperfeiçoamento de Pessoal de Nivel Superior (Chamada No. 44/2014 PAPOS-MS) by the financial suport. 


\section{References}

ADAIME, R., STRIKIS, P.C., SOUZA-FILHO, M. De., LIMA, C.R. \& LASA, R. 2012. First report of Lonchaeidae (Diptera) infesting fruits of Byrsonima crassifolia in Brazil. Rev. colomb. entomol. 38:363-364.

AGUIAR-MENEZES, E.L., NASCIMENTO, R.J \& MENEZES, E.B. 2004 Diversity of fly species (Diptera: Tephritoidea) from Passiflora spp. and their hymenopterous parasitoids in two municipalities of the southeastern Brazil. Neotrop. entomol. 33:85-89.

ALUJA, M., CELEDONIO-HURTADO, H., LIEDO, P., CABRERA, M., CASTILLO, F., GUILLÉN, J. \& RIOS, E. 1996. Seasonal population fluctuation and ecological implications for management of Anastrepha fruit flies (Diptera: Tephritidae) in commercial mango orchards in southern Mexico. J. Econ. Entomol. 89: 654-667.

ARAUJO, E.L. \& ZUCCHI, R.A. 2002. Host plants and infestation levels of Neosilba pendula (Bezzi) (Diptera: Lonchaeidae) in Mossoró/Assu, RN, Brazil. Arq. Inst. Biol. 69:91-94.

BITTENCOURT, M.A., SILVA, A.C., BOMFIM, Z.V., SILVA, V.E., ARUJO, E.L. \& STRIKIS, P.C. 2006. New records of Neosilba species (Diptera: Lonchaeidae) in Bahia State, Brazil. Neotrop. entomol. 35:282-283. http://dx.doi.org/10.1590/ S1519-566X2006000200023

BITTENCOURT, M.A.L., MENEZES, A.M.S., BOMFIM, J.P.A., SANTOS, O.O., CASTELLANI, M.A. \& STRIKIS, P.C. 2013. New records of occurrence of five species of Neosilba (Diptera: Lonchaeidae) in the State of Bahia, Brazil. Cienc. rural 43:1744-1746. http://dx.doi.org/10.1590/S0103-84782013001000002

CAREY, J.R. 1993. Applied demography for biologists with special emphasis on insects. New York. Oxford University Press, xxi+206p.

FARIA, D., LAPS, R.R., BAUMGARTEN, J. \& CETRA, M. 2006. Bat and bird assemblages from forests and shade cacao plantations in two contrasting landscapes in the Atlantic Forest of southern Bahia, Brazil. Biodivers. Conserv 15: 587-612.

FERNANDES, D.R.R., VACARI, A.M., ARAUJO, E.L., GUIMARÃES, J.A., BORTOLI, S.A. De. \& PERIOTO, N.W. 2013. Frugivorous flies (Diptera: Tephritidae and Lonchaeidae) and native parasitoids (Hymenoptera) associated with Pouteria caimito (Sapotaceae) in Brazil. Fla. entomol. 96:255-257. http:// dx.doi.org/10.1653/024.096.0139

GALEANO-OLAYA, P.E \& CANAL, N.A. 2012. New species of Neosilba McAlpine (Diptera: Lonchaeidae) and new records from Colombia. Pap. Avulsos Zool. 52:361-385.

KORYTKOWSKI, C.A. \& OJEDA, P.D. 1971. Review of the species of the family Lonchaeidae in Peru (Diptera: Acalyptratae). Rev. Peru Entomol. 14:87-116

KOVALESKI, A., SUGAYAMA, R.L \& MALAVASI, A. 1999. Movement of Anastrepha fraterculus from native breeding sites into apple orchards in Southern Brazil. Entomol. Exp. Appl. 91: 457-463.

MARTINI, A.M.Z, FIASCHI, P., AMORIM, A.M. \& PAIXÃO, J.L. 2007. A hot-point within a hot-spot: a high diversity site in Brazil's Atlantic Forest. Biodivers. Conserv. 16: 3111-3128

MCALPINE, J.F. \& STEYSKAL, G.C. 1982. A Revision of Neosilba McAlpine with a Key to world genera of Lonchaeidae (Diptera). Can. Entomol. 114:105137. http://dx.doi.org/10.4039/Ent114105-2

MORAES, R.C.B., HADDAD, M.L. \& REYES, AEL. 2003. Faunistic analysis software - AnaFau. In: Anais do VIII Simpósio de Controle Biológico - Siconbiol, 2003. São Pedro. p. 195. Resumos.

NICÁCIO, J. \& UCHOA, M.A. 2011. Diversity of frugivorous flies (Diptera: Tephritidae and Lonchaeidae) and their relationship with host plants (Angiospermae) in environments of South Pantanal region, Brazil. Fla. Entomol. 94:443-466. http://dx.doi.org/10.1653/024.094.0309

PAPADOPOULOS, N.T., KATSOYANNOS, I.B. CAREY, R.J. 2002.Demographic parameters of the Mediterranean fruit fly (Diptera: Tephritidae) reared in apples. Ann. Entomol. Soc. Am. 95: 564-569.

PEÑARANDA A., ULLOA, P.C. \& HERNÁNDEZ, M. 1986. Biology's passion fruit buds Fly Dasiops inedulis (Diptera: Lonchaeidae) in Cuaca Valley. Rev. Col. Entomol. 12:16-22.

RAGA, A., SOUZA-FILHO, M.F. \& MARTINS.V.A. 1996. Avaliação da infestação de moscas-das-frutas em variedades de café (Coffea spp.) Arq. Inst. Biol. 63: 59-63.

RAGA, A., MACHADO R.A., COSTA, A.A., SOUZA-FILHO, M.F., VEIGA, R.F.A, SAES, L.A. 2003. First occurrence of Anastrepha serpentina and Anastrephaleptozona (Dip.: Tephritidae) on abiu (Pouteria caimito) in the sate of São Paulo, Brazil. Rev. Bras. Frut. 25: 337-338.
RAGA, A., MACHADO, R.A., DINARDO, W. \& STRIKIS, P.C. 2006. Eficácia de atrativos alimentares na captura de mosca-das-frutas em pomar de citrus. Bragantia 65: 337-345.

RAGA, A., SOUZA-FILHO, M.F., MACHADO, R.A., SATO, M.E., SILOTO, R.C. 2011. Host Ranges and infestation indices of fruit flies (Tephritidae) and lance flies (Lonchaeidae) in São Paulo State, Brazil. Fla. Entomol. 94: 787-794.

RAGA, A., SOUZA-FILHO, M.F., STRIKIS, P.C. \& MONTES, S. M.N.M. 2015. Lance fly (Diptera: Lonchaeidae) host plants in the State of São Paulo, Southeast Brazil. Entomotropica 30: 57-68.

SÁNCHEZ, H., BLANCO, G., CALVO, A. \& SHANNON, P. 1991. Evaluation of four insecticides for the control of the fly of the Chilean Neosilba spp. (Diptera: Lonchaeidae), under two management systems. Manejo Integrado de Plagas 20:57-60.

SETZER, J. 1976. Atlas climático do estado de São Paulo. São Paulo, Secretaria da Agricultura, 98p.

SILVA, F. F. DA, MEIRELLES, R. N., REDAELLI, L. R. \& DAL SOGLIO, F. K. 2006. Diversity of flies (Diptera: Tephritidae and Lonchaeidae) in organic citrus orchards in the Vale do Rio Caí, Rio Grande do Sul, Southern Brazil. Neotrop. Entomol. 35: 666-670.

SILVEIRA NETO, S., NAKANO, O., BARBIN, D., \& VILLA NOVA, N. 1976 Manual de ecologia dos insetos. São Paulo, Ceres, 419 pp.

SOUZA, A.R., LOPES-MIELEZRSKI, G.N., LOPES, E.N., QUERINO, R.B., CORSATO, C.D.A., GIUSTOLIN, T.A. \& ZUCCHI, R.A. 2012. Hymenopteran parasitoids associated with frugivorous larvae in a Brazilian Caatinga-Cerrado ecotone. Environ. Entomol. 41:233-237. http://dx.doi.org/10.1603/EN11121

SOUZA-FILHO, M.F., RAGA, A., AZEVEDO-FILHO, J.A., STRIKIS, P.C., GUIMARÃES, J.A. \& ZUCCHI, R.A 2009. Diversity and seasonality of fruit flies (Diptera: Tephritidae and Lonchaeidae) and their parasitoids (Hymenoptera: Braconidae and Figitidae) in orchards of guava, loquat and peach. Braz. J. Biol. 69:31-40.

STEYSKAL, G.C. 1978. A new pest of chili peppers in Colombia (Diptera: Lonchaeidae). Cooperative Plant Pest Report 3:72-73.

STRIKIS, P. C. \& PRADO, A.P. 2005. A new species of the genus Neosilba (Diptera: Lonchaeidae). Zootaxa 828:1-4

STRIKIS, P.C. 2011. Description of 11 new species of genus Neosilba (Diptera: Lonchaeidae) from Brazil, its hosts and geographical distribution. Trends in Entomology 7:67-79.

STRIKIS, P.C., DEUS, E.G., SILVA, R.A., PEREIRA, J.D.B., JESUS, C.R. \& MARSARO JÚNIOR, A.L. 2011. Conhecimento sobre Lonchaeidae na Amazônia brasileira. In Moscas-das-frutas na Amazônia brasileira: diversidade, hospedeiros e inimigos naturais (SILVA, R.A., LEMOS, W.P. \& R.A. ZUCCHI, EDS.) Embrapa Amapá, Macapá, p.205-216.

THOMAS, W.W., CARVALHO, A.M.V., AMORIM, A.M.A., GARRISON, J. \& ARBELA'EZ, A.L. 1998. Plant endemism in two forests in southern Bahia, Brazil. Biodivers. Conserv. 7: 311-322.

UCHOA, M.A. \& ZUCCHI, R.A. 1999. Methodology for collecting true fruit flies, frugivorous Lonchaeids, and their Hymenopteran parasitoids. An. Soc. Entomol. Brasil 28:601-610.

UCHOA, M.A., OLIVEIRA, I., MOLINA, R.M.S. \& ZUCCHI, R.A. 2002. Species diversity of frugivorous flies (Diptera: Tephritoidea) from hosts in the cerrado of the state of Mato Grosso do Sul, Brazil. Neotrop. Entomol. 31:515-524. http://dx.doi.org/10.1590/S1519-566X2002000400002

UCHOA, M.A., CAIRES, C.S., NICÁCIO, J.N. \& DUARTE, M. 2012. Frugivory of Neosilba species (Diptera: Lonchaeidae) and Thepytus echelta (Lepidoptera: Lycaenidae) on Psittacanthus (Santalales: Loranthaceae) in ecotonal Cerrado-South Pantanal, Brazil. Fla. Entomol. 95:630-640. http://dx.doi.org/10.1653/024.095.0314

VARGAS, R.I., PECK, S.L., MCQUATE, G.T., JACKSON, C.G., STARK, J.D., ARMSTRONG, J.W. 2001. Potential for area wide integrated management of Mediterranean fruit fly (Diptera: Tephritidae) with a braconid parasitoid and a novel bait spray. J. Econ. Entomol. 94: 817-825.

Received: 10/06/2016

Revised: $27 / 12 / 2016$

Accepted: 15/02/2017

Published online: 13/03/2017 